\title{
PEMBERIAN BEBERAPA ZPT ORGANIK TERHADAP BEBERAPA VARIETAS BIBIT KELAPA SAWIT (Elaeis guineensis Jacq.) DI PRE-NURSERY
}

\author{
Yazid Habiby Lubis ${ }^{1}$, Mita Setyowati ${ }^{2}$, Aboe B. Saidi ${ }^{2}$ \\ ${ }^{1}$ Alumni Prodi Agroteknologi, Fakultas Pertanian, Universitas Teuku Umar, \\ ${ }^{2}$ Prodi Agroteknologi, Fakultas Pertanian, Universitas Teuku Umar, Meulaboh \\ Email korespondensi: yazidhabiby77@gmail.com
}

\begin{abstract}
The aims of this study was to determine the effect of several organic growth regulatory on several varieties of oil palm seedlings (Elaeis guineensis Jacq) in Pre Nursery. The research was carried out in the experimental garden of the Faculty of Agriculture, Teuku Umar University, West Aceh, from March until finished. The materials used were Organic growth regulatory in the form of $50 \mathrm{cc}$ coconut water, $50 \mathrm{cc}$ union extract and $50 \mathrm{cc}$ bamboo shoot extract. While the varieties of oil palm seedlings are varieties that yangambi, simalungun and 239 from IOPRI Medan. This study used a factorial randomized block design (RBD) 4 $X 3$ with 3 replications. Giving growth regulatory $(Z)$ consists of 4 levels, namely: ZO= Control, $Z 1$ = Coconut water, $Z 2=$ Shallot Extract, $Z 3=$ Bamboo Extract, while Variety factor $(V)$ consists of 3 levels: $V 1=$ Yangambi, V2 = Simalungun, V3 = 239. Observation parameters are increase in seedling height $(\mathrm{cm})$, stem diameter $(\mathrm{mm})$, number of leaf midribs (midrib), wet stover weight ( $\mathrm{g}$ ), number of roots (number) and root length (cm).
\end{abstract}

Keywords: Growth Regulatory, Varieties, Oil Palm, Pre Nursery

\section{PENDAHULUAN}

Kelapa sawit (Elaeis guineensis Jacq.) merupakan salah satu primadona tanaman perkebunan yang memiliki prospek pengembangan cukup cerah. Kelapa sawit adalah tumbuhan industri/ perkebunan yang berguna sebagai penghasil minyak masak, minyak industri, maupun bahan bakar. Luas lahan perkebunan sawit Indonesia pada 2016 diperkirakan mencapai 11,67 juta hektare (ha). Jumlah ini terdiri dari perkebunan rakyat seluas 4,76 juta ha, perkebunan swasta 6,15 juta ha, dan perkebunan negara 756 ribu ha, berdasarkan data dari (Direktorat Jenderal Perkebunan Kementerian Pertanian, 2016).

Analisis faktor yang mempengaruhi produktivitas kelapa sawit tidak dapat dilakukan secara mudah mengingat banyak faktor yang mempengaruhi. Faktor-faktor yang mempengaruhi produktivitas kelapa sawit salah satunya yaitu faktor lingkungan, faktor genetik, dan teknik budidaya (Mangunsoekarjo dan Semangun, 2005). Lubis et al. (2011) menyatakan bahwa seleksi bibit yang baik akan menghasilkan tanaman yang baik ketika penanaman.

Untuk mencapai perkebunan berkelanjutan, bahan tanaman merupakan syarat mutlak untuk mencapai keberhasilan. Potensi genetik dan karakter tanaman yang memiliki keunggulan kompetitif tergambar pada deskripsi varietas tanaman (Mangoensokarjo dan Semangun, 2005).

Konsep zat pengatur tumbuh diawali dengan konsep hormon tanaman. Hormon tanaman adalah senyawasenyawa organik tanaman yang dalam konsentrasi yang rendah mempengaruhi proses-proses fisiologis. Proses-proses fisiologis ini terutama tentang proses pertumbuhan, differensiasi dan 
perkembangan tanaman (Salisbury, 1995).

Hasil penelitian Maretza (2009) melaporkan bahwa penggunaan ekstrak rebung bambu pada persemaian sengon akan efektif untuk memacu pertumbuhan bibit sengon pada dosis $20 \mathrm{ml} / \mathrm{bibit}$ sampai dengan $50 \mathrm{ml} /$ bibit. Sedangkan giberelin yang berasal dari rebung bambu berfungsi untuk pemanjangan batang dan pertumbuhan daun serta mendorong pembungaan dan perkembangan buah.

\section{METODE PENELITIAN}

Penelitian dilaksanakan di kebun percobaan Fakultas Pertanian Universitas Teuku Umar, Meulaboh yang dilaksanakan pada Maret sampai September 2018. Bahan yang digunakan adalah air kelapa, ekstrak bawang merah dan ekstrak rebung sebagai sumber ZPT organik, bibit kelapa sawit varietas yangambi, simalungun dan DxP 239.

Metode penelitian yang digunakan adalah eksperimen dengan menggunakan Rancangan Acak Kelompok (RAK) yang terdiri dari 4 perlakuan dan 3 ulangan sehingga diperoleh 12 unit percobaan. Adapun Perlakuan yang dicobakan adalah Z0: Tanpa ZPT, Z1: air kelapa $50 \mathrm{ml}, \mathrm{Z2}$ : ekstrak bawang merah $50 \mathrm{ml}, \mathrm{Z3}$ : ekstrak rebung $50 \mathrm{ml}$, dengan varietas $\mathrm{V} 1$ : yangambi, V2 : simalungun, V3 : 239.

\section{HASIL DAN PEMBAHASAN}

Pengaruh Pemberian Beberapa ZPT Organik Terhadap Bibit Kelapa Sawit (Elaeis guineensis Jacq.) Di Pre Nursery

Pertambahan Tinggi Bibit

Tabel 1 menunjukkan bahwa pertambahan tinggi bibit kelapa sawit umur 6,8 dan 10 MST tidak berbeda pada perlakuan $\mathrm{Z}_{0}$ (tanpa ZPT), $\mathrm{Z}_{1}$ (air kelapa), $Z_{2}$ (ekstrak bawang merah) dan $\mathrm{Z}_{3}$ (ekstrak rebung). Sementara pada umur 12 MST tinggi bibit dijumpai pada pengaruh $Z_{1}$ (air kelapa) dan $Z_{3}$ (ekstrak rebung) yang berbeda terhadap pengaruh $\mathrm{Z}_{0}$ (tanpa $\mathrm{ZPT}$ ) dan $\mathrm{Z}_{2}$ (ekstrak bawang merah).

Tabel 1. Rata-rata Pertambahan Tinggi Bibit Kelapa Sawit Umur 6, 8, 10 dan 12 MST Pada Pemberian Beberapa ZPT Organik

\begin{tabular}{|c|c|c|c|c|c|}
\hline \multirow{2}{*}{ Umur Tanaman } & \multicolumn{4}{|c|}{ Pengaruh ZPT } & \multirow[t]{2}{*}{ BNT 0,05} \\
\hline & $\mathrm{Z}_{0}$ & $\mathrm{Z}_{1}$ & $\mathrm{Z}_{2}$ & $\mathrm{Z}_{3}$ & \\
\hline $6 \mathrm{MST}$ & 4,44 & 4,51 & 4,40 & 4,60 & \\
\hline $8 \mathrm{MST}$ & 4,76 & 4,77 & 4,66 & 4,69 & \\
\hline $10 \mathrm{MST}$ & 4,03 & 4,13 & 4,09 & 4,05 & \\
\hline $12 \mathrm{MST}$ & $3,93 \mathrm{a}$ & $4,40 \mathrm{~b}$ & $3,98 \mathrm{a}$ & $4,23 \mathrm{~b}$ & 0,32 \\
\hline
\end{tabular}

Keterangan: Angka yang diikuti oleh huruf yang sama pada baris yang sama tidak berbeda nyata pada taraf peluang $5 \%\left(\right.$ BNT. $\left._{.0 .05}\right)$.

Pemberian beberapa ZPT organik tidak berpengaruh terhadap pertambahan tinggi bibit pada umur 6,8 , dan 10 MST, karena kandungan pemberian beberapa ZPT pada awal pertumbuhan tinggi bibit kelapa sawit belum dipengaruhi oleh hormon. Sesuai penelitian Rahmi et al., (2013) Berdasarkan hasil analisis ragam tinggi bibit kelapa sawit pada pemberian air kelapa, ekstrak bawang merah dan ekstrak rebung pada umur 4 MST menunjukkan pengaruh yang tidak nyata sedangkan pada umur 6-12 MST menunjukkan pengaruh yang nyata.

Berpengaruhnya pemberian beberapa ZPT organik pada umur 12 MST, karena pada saat itu akar telah sepenuhnya menyerap hormon dari ZPT sehingga kandungan hormonnya cepat diterima oleh akar dan dikirm ke semua jaringan tanaman yang menyebabkan mudahnya proses metabolisme pada tanaman bibit kelapa sawit. Menurut 
penelitian Sudarso et al. (2015) menyatakan bahwa pemberian ZPT asal air kelapa dan rebung bambu meningkatkan pertambahan tinggi bibit kelapa sawit lebih besar dari pada ZPT ekstrak bawang merah.

\section{Diameter Pangkal Batang}

Tabel 2 menunjukkan bahwa diameter pangkal batang bibit kelapa sawit umur 4, 6, 8 dan 10 MST tidak berbeda pada perlakuan $\mathrm{Z}_{0}$ (tanpa ZPT), $\mathrm{Z}_{1}$ (air kelapa), $\mathrm{Z}_{2}$ (ekstrak bawang merah) dan $Z_{3}$ (ekstrak rebung). Sementara pada umur 12 MST diameter pangkal batang bibit kelapa sawit dijumpai pada pengaruh $\mathrm{Z}_{1}$ (air kelapa) dan $Z_{3}$ (ekstrak rebung) yang berbeda terhadap pengaruh $\mathrm{Z}_{0}(\operatorname{tanpa} \mathrm{ZPT})$ dan $\mathrm{Z}_{2}$ (ekstrak bawang merah).

Tabel 2. Rata-rata Diameter Pangkal Batang Bibit Kelapa Sawit Umur 4, 6, 8, 10 dan 12 MST Pada Pemberian Beberapa ZPT Organik

\begin{tabular}{|c|c|c|c|c|c|}
\hline \multirow{2}{*}{ Umur Tanaman } & \multicolumn{4}{|c|}{ Pengaruh ZPT } & \multirow{2}{*}{ BNT 0,05} \\
\hline & $\mathrm{Z}_{0}$ & $\mathrm{Z}_{1}$ & $\mathrm{Z}_{2}$ & $\mathrm{Z}_{3}$ & \\
\hline $4 \mathrm{MST}$ & 5,06 & 5,19 & 5,07 & 5,04 & \\
\hline $6 \mathrm{MST}$ & 5,43 & 5,91 & 5,69 & 5,72 & \\
\hline $8 \mathrm{MST}$ & 7,12 & 7,32 & 7,25 & 7,30 & \\
\hline $10 \mathrm{MST}$ & 8,99 & 9,25 & 9,12 & 9,23 & \\
\hline $12 \mathrm{MST}$ & $11,17 \mathrm{a}$ & $12,25 \mathrm{~b}$ & $11,22 \mathrm{a}$ & $12,08 \mathrm{~b}$ & 0,78 \\
\hline
\end{tabular}

Keterangan : Angka yang diikuti oleh huruf yang sama pada baris yang sama tidak berbeda nyata pada taraf peluang $5 \%$ (BNT.0.05).

Pemberian beberapa ZPT organik tidak berpengaruh terhadap diameter pangkal batang pada umur 4,6 , 8, dan 10 MST, karena tanaman kelapa sawit membutuhkan waktu terhadap merespon kandungan hormon dari ZPT. Sejalan dengan penelitian Abdullah S dan Gusniwati (2014) berdasarkan hasil sidik ragam diameter batang bibit kelapa sawit pada pemberian air kelapa dan ekstrak rebung belum berpengaruh pada bibit sawit umur 4-6 MST.

Peningkatan diameter batang pada umur 12 MST disebabkan faktor hormon dari ZPT. Sesuai Poerwowidodo
(1992) yang menyatakan bahwa pada fase tertentu tanaman dapat mengalami pertambahan diameter pangkal batang yang berkaitan erat dengan faktor dari kandungan hormon ZPT.

\section{Jumlah Pelepah Daun}

Tabel 3 menunjukkan bahwa jumlah pelepah daun bibit kelapa sawit umur 4, 6, 8, 10 dan 12 MST tidak berbeda pada semua perlakuan dan pengamatan di $Z_{0}$ (tanpa ZPT), $Z_{1}$ (air kelapa), $Z_{2}$ (ekstrak bawang merah) dan $\mathrm{Z}_{3}$ (ekstrak rebung).

Tabel 3. Rata-rata Jumlah Pelepah Daun Bibit Kelapa Sawit Umur 4, 6, 8, 10 dan 12 MST Pada Pemberian Beberapa ZPT Organik

\begin{tabular}{cccccc}
\hline \multirow{2}{*}{ Umur Tanaman } & \multicolumn{4}{c}{ Pengaruh ZPT } & \multirow{2}{*}{ BNT 0,05 } \\
\cline { 2 - 4 } & $\mathrm{Z}_{0}$ & $\mathrm{Z}_{1}$ & $\mathrm{Z}_{2}$ & $\mathrm{Z}_{3}$ & \\
\hline 4 MST & 0,47 & 0,48 & 0,43 & 0,59 & \\
6 MST & 0,70 & 0,85 & 0,60 & 0,81 & \\
8 MST & 1,48 & 1,52 & 1,41 & 1,48 & \\
10 MST & 1,77 & 1,79 & 1,65 & 1,78 & \\
12 MST & 2,36 & 2,53 & 2,44 & 2,49 & \\
\hline
\end{tabular}


Pemberian beberapa ZPT organik tidak berpengaruh terhadap jumlah pelepah daun terhadap semua umur parameter pengamatan, karena ZPT yang diberikan belum dapat memacu perbedaan jumlah daun pada bibit kelapa sawit. Sesuai penelitian Haridman et al. (2014) yang menyatakan bahwa pemberian zat pengatur tumbuh alami menunjukkan perbedaan tidak nyata terhadap jumlah daun bibit kelapa sawit, karena pada pemberian beberapa ZPT yang diberikan belum mampu memenuhi kecukupan hormon untuk pertumbuhan jumlah daun bibit kelapa sawit.

\section{Berat Berangkasan Basah}

Tabel 4 menunjukkan bahwa berat brangkasan basah bibit kelapa sawit berpengaruh pada umur 12 MST dijumpai di pemberian $\mathrm{Z}_{1}$ (air kelapa), $\mathrm{Z}_{2}$ (ekstrak bawang merah) dan $Z_{3}$ (ekstrak rebung) dan berbeda terhadap pengaruh $\mathrm{Z}_{0}(\operatorname{tanpa} \mathrm{ZPT})$.

Tabel 4. Rata-rata berat berangkasan basah bibit kelapa sawit pada pemberian beberapa zpt organik

\begin{tabular}{cccccc}
\hline \multirow{2}{*}{ Pengamatan } & \multicolumn{4}{c}{ Pengaruh $\mathrm{ZPT}$} & \multicolumn{1}{c}{ BNT } \\
& $\mathrm{Z}_{0}$ & $\mathrm{Z}_{1}$ & $\mathrm{Z}_{2}$ & $\mathrm{Z}_{3}$ & \\
\cline { 2 - 7 } & $4,78 \mathrm{a}$ & $5,46 \mathrm{~b}$ & $5,28 \mathrm{~b}$ & $5,31 \mathrm{~b}$ & 0,42 \\
\hline Berat Berangkasan Basah & &
\end{tabular}

Keterangan: Angka yang diikuti oleh huruf yang sama pada baris yang sama tidak berbeda nyata pada taraf

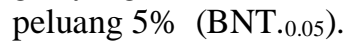

Pemberian beberapa ZPT organik berpengaruh terhadap berat brangkasan basah, karena laju respon oleh bibit terhadap hormon ZPT dapat meningkatkan pertumbuhan bibit pada umur 12 MST (Tabel 2 dan 3) yang mencerminkan berat berangkasan basah. Pertumbuhan ditandai dengan peningkatan ukuran dan jumlah sel. Poerwowidodo, (1992) menyatakan bahwa berat berangkasan basah juga mencerminkan status nutrisi tanaman karena berat basah tersebut tergantung pada jumlah sel, ukuran sel atau kualitas sel penyusun tanaman, hal ini tergantung pada ketersediaan hormon dan jumlah akumulasi senyawa organik dari hasil fotosintesis, merupakan cerminan dari kemampuan tanaman menyerap hormon dari kandungan ZPT.

\section{Jumlah Akar}

Tabel 5 menunjukkan bahwa jumlah akar bibit kelapa sawit umur 12 MST berpengaruh dijumpai pada perlakuan $Z_{1}$ (air kelapa) yang tidak berbeda dengan perlakuan $Z_{3}$ (ekstrak rebung) dan $Z_{2}$ (ekstrak bawang merah) namun tidak berbeda nyata dengan perlakuan $\mathrm{Z}_{0}$ (Tanpa ZPT).

Tabel 5. Rata-rata jumlah akar bibit kelapa sawit pada pemberian beberapa zpt organik

\begin{tabular}{cccccc}
\hline \multirow{2}{*}{ Pengamatan } & \multicolumn{4}{c}{ Pengaruh $\mathrm{ZPT}$} & \multicolumn{1}{c}{$\mathrm{BNT}$} \\
& $\mathrm{Z}_{0}$ & $\mathrm{Z}_{1}$ & $\mathrm{Z}_{2}$ & $\mathrm{Z}_{3}$ & 0,05 \\
\hline $\begin{array}{c}\text { Jumlah Akar } \\
\text { (jumlah) }\end{array}$ & $2,8 \mathrm{a}$ & $3,4 \mathrm{~b}$ & $3,1 \mathrm{a}$ & $3,2 \mathrm{ab}$ & 0,33 \\
\hline
\end{tabular}

Keterangan: Angka yang diikuti oleh huruf yang sama pada baris yang sama tidak berbeda nyata pada taraf peluang $5 \%\left(\right.$ BNT. $\left._{0.05}\right)$.

Pemberian beberapa ZPT organik berpengaruh terhadap jumlah akar, karena laju respon oleh bibit kelapa sawit terhadap hormon ZPT lebih berpengaruh dibandingkan dengan perlakuan tanpa
ZPT. Pendapat Lakitan, (2000) yang mengatakan bahwa kemampuan jaringan untuk tumbuh jumlah akar bergantung pada zat pengatur tumbuh (ZPT) yang ditambahkan ke dalam media, antara lain 
auksin dan kurangnya dosis juga akan mempengaruhi pertumbuhan jumlah akarnya.

\section{Panjang Akar}

Tabel 6 menunjukkan bahwa panjang akar bibit kelapa sawit umur 12
MST berpengaruh dijumpai pada perlakuan $\mathrm{Z}_{1}$ (air kelapa) yang berbeda dengan perlakuan $\mathrm{Z}_{0}$ (tanpa $\mathrm{zpt}$ ), $\mathrm{Z}_{2}$ (ekstrak bawang merah) dan $\mathrm{Z}_{3}$ (ekstrak rebung).

Tabel 6. Rata-rata panjang akar bibit kelapa sawit pada pemberian beberapa zpt organik

\begin{tabular}{cccccc}
\hline \multirow{2}{*}{ Pengamatan } & \multicolumn{4}{c}{ Pengaruh ZPT } & \multicolumn{2}{c}{ BNT } \\
& $\mathrm{Z}_{0}$ & $\mathrm{Z}_{1}$ & $\mathrm{Z}_{2}$ & $\mathrm{Z}_{3}$ & 0,05 \\
\hline Panjang Akar $(\mathrm{cm})$ & $23,63 \mathrm{a}$ & $24,51 \mathrm{~b}$ & $23,04 \mathrm{a}$ & $23,66 \mathrm{a}$ & 0,82 \\
\hline
\end{tabular}

Keterangan: Angka yang diikuti oleh huruf yang sama pada baris yang sama tidak berbeda nyata pada taraf peluang 5\% (BNT.0.05).

Pemberian beberapa ZPT organik berpengaruh terhadap panjang akar, karena laju respon oleh bibit terhadap hormon ZPT lebih berpengaruh dibandingkan dengan perlakuan tanpa ZPT. Hal ini diduga karena pada kandungan zat pengatur tumbuh $\mathrm{Z}_{1}$ (air kelapa) mengandung hormon auksin yang dimana hormon tersebut sangat membantu dalam menunjang perakaran. Mekanisme kerja auksin akan mempengaruhi pemanjangan sel-sel pada tanaman, dan cara kerja auksin adalah dengan cara mempengaruhi pengendoran / pelenturan dinding sel (Rusmin, 2011).
Pengaruh Beberapa Varietas Bibit Kelapa Sawit (Elaeis guineensis Jacq) Di Pre Nursery

\section{Pertambahan Tinggi Bibit}

Tabel 7 menunjukkan bahwa pertambahan tinggi bibit kelapa sawit umur 6 MST berpengaruh dijumpai pada pertumbuhan varietas terbaik $\mathrm{V}_{3}$ (varietas 239) yang berbeda dengan pertumbuhan tinggi bibit $\mathrm{V}_{1}$ (varietas yangambi) dan $\mathrm{V}_{2}$ (varietas simalungun). Sedangkan pada umur 8, 10 dan 12 MST di semua pertumbuhan tinggi bibit varietas seperti $\mathrm{V}_{1}$ (varietas yangambi), $\mathrm{V}_{2}$ (varietas simalungun) dan $\mathrm{V}_{3}$ (varietas 239) tidak ada yang berbeda.

Tabel 7. Rata-rata pertambahan tinggi bibit kelapa sawit umur 6, 8, 10 dan 12 mst pada beberapa varietas

\begin{tabular}{ccccc}
\hline \multirow{2}{*}{ Umur Tanaman } & \multicolumn{3}{c}{ Pengaruh Varietas } & BNT 0,05 \\
\cline { 2 - 5 } & $\mathrm{V}_{1}$ & $\mathrm{~V}_{2}$ & $\mathrm{~V}_{3}$ & 0,29 \\
6 MST & $4,33 \mathrm{a}$ & $4,45 \mathrm{a}$ & $4,69 \mathrm{~b}$ & \\
8 MST & 4,71 & 4,77 & 4,68 & \\
10 MST & 4,14 & 4,08 & 4,01 & \\
12 MST & 4,12 & 4,22 & 4,08 & \\
\hline
\end{tabular}

Keterangan: Angka yang diikuti oleh huruf yang sama pada baris yang sama tidak berbeda nyata pada taraf peluang 5\% (BNT.0.05).

Pengaruh beberapa varietas bibit kelapa sawit terhadap pertambahan tinggi bibit pada umur 6 MST. Hal ini bahwasanya pada pertambahan tinggi bibit varietas 239 pada umur 6 MST lebih cepat pertumbuhannya karena varietas bibit memiliki tingkat cadangan makanan yang cukup. Sebagaimana yang di jelaskan oleh Ruchjaningsih et al. (2000) menyatakan bahwa genetik suatu tanaman memiliki sifat dan karakter tertentu yang menyebabkan perbedaan antar varietas tanaman satu dengan lainnya. 
Setelah berumur 8, 10 dan 12 MST ketiga varietas bibit kelapa sawit tidak berbeda laju pertambahan tingginya. Hasil ini berkaitan dengan sifat dan daya adaptasi suatu varietas terhadap lingkungannya. Suatu varietas tertentu pertumbuhannya akan maksimal apabila lingkungan tumbuhnya sesuai dengan syarat tumbuhnya, Jedeng (2011).

\section{Diameter Pangkal Batang}

Tabel 8 menunjukkan bahwa diameter pangkal batang berpengaruh pada umur 4 MST dijumpai pada $V_{3}$ (varietas 239) yang berbeda dengan $\mathrm{V}_{1}$ (varietas yangambi) dan $\mathrm{V}_{2}$ (varietas simalungun). Sedangkan pada umur 6, 8, 10 dan 12 MST di semua pertumbuhan diameter pangkal batang seperti $\mathrm{V}_{1}$, (varietas yangambi), $\mathrm{V}_{2}$ (varietas simalungun) dan $\mathrm{V}_{3}$ (varietas 239) tidak ada yang berpengaruh.

Pengaruh beberapa varietas bibit kelapa sawit terhadap pertumbuhan diameter pangkal batang pada umur 4 MST. Sebagaimana yang dijelaskan oleh Jedeng (2011) yang menyatakan bahwa faktor varietas turut menentukan tingkat pertumbuhan tanaman dilapangan dan secara umum suatu tanaman tergantung dari varietas yang digunakan. Perbedaan varietas diharapkan peranannya untuk memanfaatkan lingkungan guna mencapai potensial hasil yang tinggi.

Tabel 8. Rata-rata diameter pangkal batang bibit kelapa sawit umur 4, 6, 8, 10 dan 12 mst pada beberapa varietas

\begin{tabular}{ccccc}
\hline \multirow{2}{*}{ Umur Tanaman } & \multicolumn{3}{c}{ Pengaruh Varietas } & BNT 0,05 \\
\cline { 2 - 5 } & $\mathrm{V}_{1}$ & $\mathrm{~V}_{2}$ & $\mathrm{~V}_{3}$ & 0,38 \\
4 MST & $5,08 \mathrm{a}$ & $4,84 \mathrm{a}$ & $5,34 \mathrm{~b}$ & \\
6 MST & 5,46 & 5,67 & 5,94 & \\
8 MST & 7,11 & 7,25 & 7,39 & \\
10 MST & 8,91 & 9,12 & 9,40 & \\
12 MST & 11,39 & 11,69 & 11,96 & \\
\hline
\end{tabular}

Keterangan : Angka yang diikuti oleh huruf yang sama pada baris yang sama tidak berbeda nyata pada taraf peluang $5 \%($ BNT.0.05). .

Setelah berumur 6, 8, 10 dan 12 MST ketiga varietas bibit kelapa sawit telah bersamaan pertumbuhannya sehingga pertumbuhan diameter pangkal batang tidak menunjukkan perbedaan pada masing - masing varietas. Hal ini diduga karena faktor varietas memiliki kemiripan satu keturunan varietas yang sama dari tanaman tetuanya. Sebagaimana yang dijelaskan Pahan (2008) bahwa potensi hasil suatu varietas tertentu tidak dapat dipisahkan dengan tingkat adaptasi maupun keturanan dan kemantapan penampilannya pada suatu lingkungan tumbuh.

\section{Jumlah Pelepah Daun}

Tabel 9 menunjukkan bahwa jumlah pelepah daun berpengaruh pada umur 4 MST dijumpai pada $\mathrm{V}_{3}$ (varietas
239) yang berbeda dengan $V_{1}$ (varietas yangambi) dan $\mathrm{V}_{2}$ (varietas simalungun). Sedangkan pada umur 6, 8, 10 dan 12 MST di semua pertambahan jumlah pelepah daun seperti $\mathrm{V}_{1}$, (varietas yangambi), $V_{2}$ (varietas simalungun) dan $\mathrm{V}_{3}$ (varietas 239) tidak ada yang berpengaruh.

Pengaruh beberapa varietas bibit kelapa sawit terhadap pertumbuhan jumlah pelepah daun pada umur 4 MST. Hal ini diduga adanya perbedaan antara jumlah pelepah daun pada beberapa varietas bibit kelapa sawit. Dapat diketahui bahwa $\mathrm{V}_{3}$ (varietas 239) memiliki daya berkecambah tunas yang lebih cepat dibandingkan dengan $\mathrm{V}_{1}$ (varietas yangambi) dan $V_{2}$ (varietas simalungun). 
Tabel 9. Rata-rata jumlah pelepah daun pada beberapa varietas bibit kelapa sawit umur 4, $6,8,10$ dan $12 \mathrm{mst}$

\begin{tabular}{ccccc}
\hline Umur & \multicolumn{3}{c}{ Pengaruh Varietas } & BNT 0,05 \\
\cline { 2 - 5 } Tanaman & $\mathrm{V}_{1}$ & $\mathrm{~V}_{2}$ & $\mathrm{~V}_{3}$ & \\
\hline 4 MST & $0,41 \mathrm{a}$ & $0,47 \mathrm{a}$ & $0,60 \mathrm{~b}$ & 0,12 \\
6 MST & 0,72 & 0,67 & 0,84 & \\
8 MST & 1,50 & 1,39 & 1,52 & \\
10 MST & 1,69 & 1,77 & 1,78 & \\
12 MST & 2,45 & 2,43 & 2,48 & \\
\hline
\end{tabular}

Keterangan: Angka yang diikuti oleh huruf yang sama pada baris yang sama tidak berbeda nyata pada taraf peluang 5\% (BNT.0.05).

Setelah umur 6, 8, 10 dan 12 MST varietas memiliki kesesuaian adaptasi lingkungan yang baik sehingga bibit ketiga varietas tumbuh optimal secara bersamaan. Untuk parameter jumlah daun beberapa varietas tidak berpengaruh. Ruchjaningsih et al. (2000) menyatakan bahwa genetik suatu tanaman memiliki sifat dan karakter tertentu yang menyebabkan perbedaan antar tanaman dan juga antar varietas satu dengan lainnya.

\section{Berat Berangkasan Basah}

Tabel 10. menunjukkan bahwa berat brangkasan basah bibit kelapa sawit tidak berpengaruh pada semua perlakuan $\mathrm{V}_{1}$ (varietas yangambi), $\mathrm{V}_{2}$ (varietas simalungun) dan $\mathrm{V}_{3}$ (varietas 239).

Tabel 10. Rata-rata berat berangkasan basah bibit kelapa sawit pada beberapa varietas

\begin{tabular}{|c|c|c|c|c|}
\hline \multirow{2}{*}{ Pengamatan } & \multicolumn{3}{|c|}{ Pengaruh Varietas } & BNT 0,05 \\
\hline & $\mathrm{V}_{1}$ & $\mathrm{~V}_{2}$ & $\mathrm{~V}_{3}$ & \\
\hline $\begin{array}{c}\text { Berat Berangkasan } \\
\text { Basah (gr) }\end{array}$ & 5,19 & 5,13 & 5,30 & \\
\hline
\end{tabular}

Faktor beberapa varietas tidak memberikan perbedaan terhadap berat brangkasan basah. Hal ini diduga dari daya perkecambahannya serta faktor dari varietas unggul yang baik menjadikan bibit kelapa sawit secara bersamaan masa pertumbuhannya yang menyebabkan tidak adanya perbedaan dari ketiga varietas tersebut. Ruchjaningsih et al. (2000) menyatakan bahwa sebagian genetik suatu varietas tanaman yang memiliki sifat keturunan dan karakter yang sama sehingga pada saat pertumbuhannya memiliki daya pertumbuhan yang serentak.

\section{Jumlah Akar}

Tabel 11 menunjukkan bahwa jumlah akar bibit kelapa sawit tidak berpengaruh pada perlakuan $\mathrm{V}_{1}$ (varietas yangambi), $\mathrm{V}_{2}$ (varietas simalungun) dan $\mathrm{V}_{3}$ (varietas 239).

Tabel 11. Rata-rata jumlah akar bibit kelapa sawit pada beberapa varietas

\begin{tabular}{ccccc}
\hline \multirow{2}{*}{ Pengamatan } & \multicolumn{3}{c}{ Pengaruh Varietas } & BNT 0,05 \\
\cline { 2 - 5 } & $\mathrm{V}_{1}$ & $\mathrm{~V}_{2}$ & $\mathrm{~V}_{3}$ & \\
\hline Jumlah akar (jumlah) & 2,94 & 3,18 & 3,23 & \\
\hline
\end{tabular}

Faktor Beberapa varietas bibit kelapa sawit tidak berpengaruh terhadap jumlah akar, karena beberapa varietas tidak memberikan perbedaan terhadap jumlah akar. Hal ini dikarenakan bahwa potensi hasil suatu varietas tertentu tidak dapat dipisahkan dengan adaptasi maupun kemantapan penampilannya 
pada suatu lingkungan tumbuh Ruchjaningsih et al. (2000). Sehingga jumlah akar bibit kelapa sawit tidak ada yang berbeda. Faktor beberapa varietas bibit kelapa sawit juga menentukan karena ketiga varietas yang merupakan hasil seleksi dari keturunan varietas unggul yang sama yang menyebabkan ketiga varietas tersebut memiliki daya pertumbuhan serentak.

Panjang Akar

Tabel 12 menunjukkan bahwa panjang akar bibit kelapa sawit tidak berpengaruh pada peralakuan $\mathrm{V}_{1}$ (varietas yangambi), $V_{2}$ (varietas simalungun) dan $\mathrm{V}_{3}$ (varietas 239).

Tabel 12. Rata-rata panjang akar bibit kelapa sawit pada pengaruh beberapa varietas

\begin{tabular}{ccccc}
\hline \multirow{2}{*}{ Pengamatan } & \multicolumn{3}{c}{ Pengaruh Varietas } & BNT 0,05 \\
\cline { 2 - 5 } & $\mathrm{V}_{1}$ & $\mathrm{~V}_{2}$ & $\mathrm{~V}_{3}$ & \\
\hline Panjang Akar $(\mathrm{cm})$ & 23,27 & 23,81 & 24,05 & \\
\hline
\end{tabular}

Faktor beberapa varietas bibit kelapa sawit tidak berpengaruh terhadap panjang akar, sesuai pendapat Harjadi, (2009) bahwa varietas bibit kelapa sawit tidak berpengaruh terhadap panjang akar karena dipengaruhi oleh rintangan dalam menembus tanah serta akar ketiga varietas bibit kelapa sawit masing-masing memiliki ciri - ciri morfologi yang sama karena ketiga varietas tersebut merupakan hasil persilangan dari varietas unggul.

\section{KESIMPULAN DAN SARAN Kesimpulan}

Pemberian beberapa ZPT organik berpengaruh pada pertambahan tinggi bibit, diameter pangkal batang, berat brangkasan basah, jumlah akar dan panjang akar pada umur 12 MST. Perlakuan terbaik dijumpai pada $Z_{1}$ (air kelapa) dan $Z_{3}$ (ekstrak rebung) dan tidak berbeda dengan perlakuan $Z_{2}$ (ekstrak bawang merah).

Faktor beberapa varietas bibit kelapa sawit tidak berpengaruh pada pertambahan tinggi bibit, diameter pangkal batang, jumlah pelepah daun, berat berangkasan basah, jumlah akar dan panjang akar pada semua parameter pengamatan. Kombinasi pemberian beberapa ZPT organik terhadap beberapa varietas bibit kelapa sawit tidak terdapat interaksi pada semua parameter pengamatan.

\section{Saran}

Perlu dilakukan penelitian lebih lanjut terhadap penggunaan dosis beberapa ZPT organik terhadap beberapa varietas bibit kelapa sawit.

\section{DAFTAR PUSTAKA}

Abdullah Samosir Dan Gusniwati. 2014. Pengaruh Rebung Bambu Terhadap Pertumbuhan Bibit Kelapa Sawit (Elaeis guineensis Jacq) Di Pre Nursery. Fakultas Pertanian, Universitas Jambi.

Direktorat Jenderal Perkebunan Kementerian Pertanian. Luas lahan perkebunan sawit Indonesia pada 2016.

Haridman K, Darmawati JS. dan Sinaga RS. 2014. Uji Pertumbuhan Bibit Kelapa Sawit Dura Dan Varietas Unggul Simalungun (Elaeis guinensis Jacq.) Terhadap Pemberian Zat Pengatur Tumbuh Organik. Agrium, April 2014 Volume 18 No 3.

Harjadi. 2009. Zat Pengatur Tumbuh. PT. Gramedia. Pustaka Jakarta.

Jedeng IW. 2011. Pengaruh Jenis dan Dosis Pupuk Organik Terhadap pertumbuhan dan Hasil Ubi Jalar (Ipomoeabatatas L) Var. Lokal Ungu. Tesis.

Lakitan. 2000. Pengaruh Hormon Zat Pengatur Tumbuh Pada Fisiologi Pertumbuhan dan Perkembangan 
Tanaman. PT. Grafindo Persada. Jakarta.

Lubis RE. dan Widanarko A. 2011. Buku Pintar Kelapa Sawit. Agromedia Pustaka. Jakarta.

Mangoensoekarjo S, Semangun H. 2005. Manajemen Kelapa Sawit. Gajah Mada University Press. Yogyakarta.

Maretza DT. 2009. Pengaruh Pengaruh Dosis Ekstrak Rebung Bambu Betung (Dendrocalamus asper Backer ex Heyne) Terhadap Pertumbuhan Semai Sengon (Paraserianthes falcataria (L.) Nielsen). Institut Pertanian Bogor. Bogor.

Pahan I. 2008. Panduan Lengkap Kelapa Sawit : Manajemen Agribisnis dari Hulu hingga Hilir. Penebar Swadaya.

Poerwowidodo, 1992. Faktor Genetik Tanaman. Angkasa Persada. Bandung.

Rahmi Zulhida, Windi Rahmadi. 2013. Ekstrak Tunas Bambu (Rebung) Dan Kompos Meningkatkan Pertumbuhan Bibit Kelapa Sawit (Elaeis guineensis Jacq) Di Main Nursery. Fakultas Pertanian UMSU Medan

Ruchjaningsih, Imran A, Thamrin M, dan Kanro MZ. 2000. Penampilan Fenotif dan Beberapa Parameter Genetik Delapan Kultivar Kacang Tanah pada Lahan Sawah. Zuriat Komunikasi Pemuliaan Indonesia Jatinangor, Sumedang.

Rusmin. 2011. Pengaruh Pemberian GA3 Pada Berbagai Konsentrasi dan Lama Inbibisi Terhadap Peningkatan Viabilitas Benis Puwoceng (Pimpinella pruatjan Molk.). Jurnal Littri. Vol: 17. No: 3

Salisbury FB. dan Ross CW. 1995. Fisiologi Tumbuhan. Diterjemahkan oleh Diah. R. Lukmana. ITB. Bandung.
Sudarso, Nelvia, Khoiri MA. 2015. Pemberian Zat Pengatur Tumbuh Alami Pada Bibit Kelapa Sawit (Elaeis guineensis Jacq) Di Main-Nursery. Jom Faperta Vol. 2 No. 2 Oktober 2015. Universitas Riau. 